\title{
P355: Quality of the management tray metrological technical clinical biochemistry public laboratory
}

\author{
M Adeoti ${ }^{*}$, C Lodjou $^{2}$ \\ From 2nd International Conference on Prevention and Infection Control (ICPIC 2013) \\ Geneva, Switzerland. 25-28 June 2013
}

\section{Introduction}

Because of its role as provider of services for clinicians and their identification with the central tool for the production of the hospital, the technical platform that is the hospital laboratory and its equipment requires the development of quality assurance.

\section{Objectives}

Evaluate the quality of the metrological management of the technical elements with a view to continuous improvement of the services provided.

\section{Methods}

It is a cross-sectional study and prospective descriptive type conducted over a period of three months in clinical biochemistry laboratories of three university hospitals in Abidjan. Performed using a plug-inventory survey of twelve open-ended questions, it focused on the environmental conditions and management of the technical platform. The performance of the laboratory was been assessed against the threshold target of $80 \%$ expected the quality standard used.

\section{Results}

Averages of $67 \%$ for environmental conditions and $42.77 \%$ for equipment and instruments were observed. Only $48.15 \%$ of the equipment and measuring instruments of the three laboratories are functional, with a better score for the CHU of Cocody. The laboratory of the University Hospital of Yopougon appears better informed on the equipment and measuring instruments (78\%). Regular maintenance and the maintenance of the technical concerns only $13.33 \%$ of the equipment and measuring instruments which are less than $15 \%$ subject

${ }^{1}$ Centra Laboratory, CHU of Yopougon, Abidjan, Côte d'Ivoire

Full list of author information is available at the end of the article to a procedure known fault management operation related to.

\section{Conclusion}

These results show notable deficiencies in the practice of primary metrological activities to guarantee the reliability of the final product laboratories, and therefore emphasize the need for development of a strategy to regulate the technical tools of analysis in the context of a quality assurance process.

\section{Disclosure of interest}

None declared.

\section{Author details}

${ }^{1}$ Centra Laboratory, CHU of Yopougon, Abidjan, Côte d'Ivoire. ${ }^{2}$ Health Ministry, Cotonou, Benin.

Published: 20 June 2013

doi:10.1186/2047-2994-2-S1-P355

Cite this article as: Adeoti and Lodjou: P355: Quality of the management tray metrological technical clinical biochemistry public laboratory.

Antimicrobial Resistance and Infection Control 2013 2(Suppl 1):P355.

Submit your next manuscript to BioMed Central and take full advantage of:

- Convenient online submission

- Thorough peer review

- No space constraints or color figure charges

- Immediate publication on acceptance

- Inclusion in PubMed, CAS, Scopus and Google Scholar

- Research which is freely available for redistribution

\section{Biomed Central}

